\title{
Influence of some selected fungicides on Fusarium genus cultures growth limitation
}

\author{
Wpływ wybranych fungicydów na ograniczenie wzrostu kultur \\ rodzaju Fusarium
}

Beata Danielewicz, Romuald Gwiazdowski, Amelia Bednarek-Bartsch

\section{Summary}

Fungi of the genus Fusarium cause many serious diseases of economic importance. Sensitivity of these species to selected fungicides was evaluated in vitro. Six species of Fusarium and six fungicides: azoxystrobin, prochloraz, thiophanate-methyl, propiconazole, tebuconazole and metconazole were examined. Each species was grown on the PDA (Potato Dextrose Agar) medium supplemented with active substances in concentration of 1,10 and $100 \mathrm{ppm}$. The experiment was carried out in four replications. The results of experiment showed a diverse sensibility of Fusarium fungi to fungicides in dependence on their concentrations.

Key words: Fusarium spp., fungicide, effectiveness, petal test

\section{Streszczenie}

Grzyby rodzaju Fusarium są przyczyną wielu groźnych chorób powodujących straty w plonie o znaczeniu gospodarczym. W doświadczeniu in vitro badano wrażliwość grzybów na wybrane fungicydy. Wykorzystano sześć gatunków grzybów rodzaju Fusarium oraz 6 fungicydów pochodzących z 4 grup chemicznych: azoksystrobina, prochloraz, tiofanat metylowy, propikonazol, metkonazol i tebukonazol. Badane grzyby wyszczepiono na pożywkę PDA (Potato Dextrose Agar) z dodatkiem fungicydów w stężeniu 1, 10 oraz 100 ppm. Stwierdzono zróżnicowaną wrażliwość grzybów rodzaju Fusarium na fungicydy w zależności od ich stężenia.

Słowa kluczowe: Fusarium spp., fungicydy, skuteczność, test płytkowy

\footnotetext{
Instytut Ochrony Roślin - Państwowy Instytut Badawczy

Zakład Badania Środków Ochrony Roślin

Władysława Węgorka 20, 60-318 Poznań

B.Danielewicz@iorpib.poznan.pl
} 


\section{Wstęp / Introduction}

Grzyby rodzaju Fusarium są przyczyną wielu groźnych chorób powodujących straty $\mathrm{w}$ plonie o znaczeniu gospodarczym. Mogą wytwarzać wtórne metabolity, tzw. mikotoksyny - związki szkodliwe dla ludzi i zwierząt (Wojciechowski i wsp. 1995), stąd istnieje konieczność ich ograniczania w czasie sezonu wegetacyjnego.

Na skuteczność ograniczenia występowania Fusarium spp. duży wpływ ma właściwy dobór fungicydów (Korbas i Ławecki 2003). Do zwalczania wyżej wymienionych grzybów jest szereg fungicydów $\mathrm{z}$ różnych grup chemicznych. Jednak uzasadnione wydaje się stałe monitorowanie ich skuteczności z powodu mogącej pojawiać się odporności grzybów.

Celem przeprowadzonego doświadczenia laboratoryjnego było określenie wrażliwości grzybów rodzaju Fusarium na wybrane fungicydy w warunkach in vitro.

\section{Materiały i metody / Materials and methods}

Doświadczenie laboratoryjne wykonano w Zakładzie Badania Środków Ochrony Roślin na terenie Instytutu Ochrony Roślin - Państwowego Instytutu Badawczego w Poznaniu.

Jako mikroorganizmy wskaźnikowe użyto: $F$. avenaceum (KZF-3), F. culmorum (KZF-5), F. graminearum (KZF-1), F. oxysporum (KZF-4), F. langsethiae (KZF-2) oraz F. equiseti (KZF-6). Materiał badawczy stanowiło 6 fungicydów pochodzacych z 4 grup chemicznych: azoksystrobina (strobiluryny), prochloraz (imidazole), tiofanat metylowy (benzimidazole), propikonazol, metkonazol i tebukonazol (triazole). Doświadczenie przeprowadzono $\mathrm{w}$ warunkach in vitro. Do płynnej sterylnej pożywki PDA (Potato Dextrose Agar) o temperaturze $45^{\circ} \mathrm{C}$ dodawano testowane środki, tak aby uzyskać trzy ich stężenia: 1, 10 oraz $100 \mathrm{ppm}$. Kombinację kontrolną stanowiła pożywka bez dodatku fungicydu. Następnie pożywkę rozlano na płytki Petriego o średnicy $5 \mathrm{~cm}$. Po zestaleniu pożywki na środek szalki wykładano krążki PDA o średnicy $4 \mathrm{~mm}$ przerośnięte badaną kulturą grzyba.
Szalki przetrzymywano $\mathrm{w}$ temperaturze pokojowej. Po zarośnięciu całej płytki w próbie kontrolnej wykonano pomiary oraz określono stopień zahamowania wzrostu poszczególnych grzybów obliczając średni przyrost grzybni w centymetrach. Doświadczenie przeprowadzono w czterech powtórzeniach. Uzyskane wyniki poddano analizie statystycznej. Po stwierdzeniu istotnych różnic dokonano porównania średnich za pomocą testu t-Studenta wyznaczając najmniejszą istotną różnicę na poziomie istotności 5\% (tab. 1, 2).

\section{Wyniki i dyskusja / Results and discussion}

W przeprowadzonym doświadczeniu zauważono zróżnicowaną wrażliwość grzybów rodzaju Fusarium na użyte fungicydy w zależności od ich stężenia. W doświadczeniu zazwyczaj stwierdzano silniejsze zahamowanie wzrostu kultur poszczególnych gatunków grzybów w miarę koncentracji fungicydu w pożywce (tab. 1, 2). W grupie triazoli najsilniejsze działanie hamujące na wzrost wszystkich badanych gatunków grzybów wykazał metkonazol, co również potwierdzają inne badania (Sikora i Banachowska 2006). Tebukonazol całkowicie zahamował wzrost $F$. avenaceum oraz $F$. graminearum jedynie w dawce najwyższej, 100 ppm. Po zastosowaniu niższych stężeń wyżej wymienionych fungicydów patogeny te wykazały umiarkowaną wrażliwość. Wszystkie trzy zastosowane fungicydy $\mathrm{z}$ grupy triazoli $\mathrm{w}$ dawce najwyższej niemal całkowicie hamowały wzrost kolonii grzybów (tab. 1). W przypadku pozostałych substancji czynnych najsilniejsze oddziaływanie fungistatyczne wykazał prochloraz. Tiofanat metylowy w stężeniu 1 oraz $10 \mathrm{ppm} \mathrm{w} \mathrm{nie-}$ wielkim stopniu ograniczył wzrost kultur badanych grzybów, podobne wyniki uzyskali Frużyńska-Jóźwiak i Andrzejak (2010). W swoich badaniach Ishii i wsp. (2008) dowiedli istnienie odpornych izolatów grzyba $F$. culmorum na tę substancję. Użyta w badaniach azoksystrobina hamowała wzrost $F$. avenaceum o 81 do $85 \%$, a pozostałych gatunków grzybów o 0 do $33 \%$. $\mathrm{W}$ przypadku azoksystrobiny stwierdzano podobne hamowanie wzrostu kultur $F$. culmorum i $F$. equiseti we

Tabela 1. Procent zahamowania wzrostu badanych grzybów rodzaju Fusarium przez triazolie Table 1. Influence of triazoles on percent of growth inhibition of tested fungi of the genus Fusarium

\begin{tabular}{l|c|c|c|c|c|c|c|c|c}
\hline \multirow{2}{*}{$\begin{array}{c}\text { Gatunek } \\
\text { Species }\end{array}$} & \multicolumn{9}{|c|}{ Procent zahamowania wzrostu - Percent of growth inhibition } \\
\cline { 2 - 12 } & \multicolumn{2}{|c|}{ propiconazole $250 \mathrm{~g} / 1$} & \multicolumn{3}{c|}{ metconazole $60 \mathrm{~g} / 1$} & \multicolumn{3}{c}{ tebuconazole $250 \mathrm{~g} / 1$} \\
\cline { 2 - 12 } & $1 \mathrm{ppm}$ & $10 \mathrm{ppm}$ & $100 \mathrm{ppm}$ & $1 \mathrm{ppm}$ & $10 \mathrm{ppm}$ & $100 \mathrm{ppm}$ & $1 \mathrm{ppm}$ & $10 \mathrm{ppm}$ & $100 \mathrm{ppm}$ \\
\hline F. avenaceum & $23 \mathrm{~b}$ & $52 \mathrm{~b}$ & $93 \mathrm{a}$ & $27 \mathrm{~b}$ & $100 \mathrm{a}$ & $100 \mathrm{a}$ & $39 \mathrm{~b}$ & $40 \mathrm{a}$ & $90 \mathrm{a}$ \\
\hline F. culmorum & $99 \mathrm{e}$ & $99 \mathrm{c}$ & $100 \mathrm{a}$ & $100 \mathrm{e}$ & $100 \mathrm{a}$ & $100 \mathrm{a}$ & $100 \mathrm{e}$ & $100 \mathrm{~d}$ & $100 \mathrm{a}$ \\
\hline F. equiseti & $80 \mathrm{c}$ & $100 \mathrm{c}$ & $100 \mathrm{a}$ & $38 \mathrm{c}$ & $100 \mathrm{a}$ & $100 \mathrm{a}$ & $73 \mathrm{~d}$ & $100 \mathrm{~d}$ & $100 \mathrm{a}$ \\
\hline F. graminearum & $10 \mathrm{a}$ & $25 \mathrm{a}$ & $100 \mathrm{a}$ & $13 \mathrm{a}$ & $100 \mathrm{a}$ & $100 \mathrm{a}$ & $34 \mathrm{a}$ & $48 \mathrm{~b}$ & $100 \mathrm{a}$ \\
\hline F. langsethiae & $100 \mathrm{e}$ & $100 \mathrm{c}$ & $100 \mathrm{a}$ & $100 \mathrm{e}$ & $100 \mathrm{a}$ & $100 \mathrm{a}$ & $100 \mathrm{e}$ & $100 \mathrm{~d}$ & $100 \mathrm{a}$ \\
\hline F. oxysporum & $87 \mathrm{~d}$ & $91 \mathrm{c}$ & $94 \mathrm{a}$ & $83 \mathrm{~d}$ & $100 \mathrm{a}$ & $100 \mathrm{a}$ & $70 \mathrm{c}$ & $84 \mathrm{c}$ & $91 \mathrm{a}$ \\
\hline
\end{tabular}

Wartości średnie oznaczone tą samą literą w obrębie kolumn nie różnią się na poziomie istotności $\mathrm{p}=0,05$

Mean values marked with the same letters within a column were not statistically significant at $\mathrm{p}=0.05$ 
Tabela 2. Procent zahamowania wzrostu badanych grzybów przez strobiluryny, imidazole i benzimidazole

Table 2. Influence of: strobilurin, imidazoles, benzimidazoles on percent of growth inhibition of tested fungi

\begin{tabular}{l|c|c|c|c|c|c|c|c|c}
\hline \multirow{2}{*}{$\begin{array}{c}\text { Gatunek } \\
\text { Species }\end{array}$} & \multicolumn{9}{c}{ Procent zahamowania wzrostu - Percent of growth inhibition } \\
\cline { 2 - 12 } & \multicolumn{3}{|c|}{ azoxystrobin $250 \mathrm{~g} / 1$} & \multicolumn{3}{c}{ prochloraz 450 g/1 } & \multicolumn{3}{c}{ thiophanate-methyl 500 g/1 } \\
\cline { 2 - 12 } & $1 \mathrm{ppm}$ & $10 \mathrm{ppm}$ & $100 \mathrm{ppm}$ & $1 \mathrm{ppm}$ & $10 \mathrm{ppm}$ & $100 \mathrm{ppm}$ & $1 \mathrm{ppm}$ & $10 \mathrm{ppm}$ & $100 \mathrm{ppm}$ \\
\hline F. avenaceum & $81 \mathrm{c}$ & $84 \mathrm{~d}$ & $85 \mathrm{~d}$ & $100 \mathrm{c}$ & $100 \mathrm{~b}$ & $100 \mathrm{~b}$ & $30 \mathrm{c}$ & $33 \mathrm{~d}$ & $55 \mathrm{a}$ \\
\hline F. culmorum & $2 \mathrm{a}$ & $4 \mathrm{a}$ & $4 \mathrm{a}$ & $100 \mathrm{c}$ & $100 \mathrm{~b}$ & $100 \mathrm{~b}$ & $0 \mathrm{a}$ & $0 \mathrm{a}$ & $46 \mathrm{a}$ \\
\hline F. equiseti & $2 \mathrm{a}$ & $2 \mathrm{a}$ & $4 \mathrm{a}$ & $90 \mathrm{a}$ & $100 \mathrm{~b}$ & $100 \mathrm{~b}$ & $4 \mathrm{ab}$ & $11 \mathrm{~b}$ & $65 \mathrm{~b}$ \\
\hline F. graminearum & $17 \mathrm{~b}$ & $20 \mathrm{c}$ & $26 \mathrm{~b}$ & $93 \mathrm{~b}$ & $93 \mathrm{a}$ & $94 \mathrm{a}$ & $11 \mathrm{~b}$ & $26 \mathrm{c}$ & $72 \mathrm{~b}$ \\
\hline F. langsethiae & $0 \mathrm{a}$ & $8 \mathrm{~b}$ & $6 \mathrm{a}$ & $100 \mathrm{c}$ & $100 \mathrm{~b}$ & $100 \mathrm{~b}$ & $0 \mathrm{a}$ & $0 \mathrm{a}$ & $87 \mathrm{c}$ \\
\hline F. oxysporum & $4 \mathrm{a}$ & $21 \mathrm{c}$ & $33 \mathrm{c}$ & $100 \mathrm{c}$ & $100 \mathrm{~b}$ & $100 \mathrm{~b}$ & $0 \mathrm{a}$ & $0 \mathrm{a}$ & $53 \mathrm{a}$ \\
\hline
\end{tabular}

Wartości średnie oznaczone tą samą literą w obrębie kolumn nie różnią się na poziomie istotności p $=0,05$

Mean values marked with the same letters within a column were not statistically significant at $p=0.05$

wszystkich stężeniach. Podobne wyniki uzyskali Gwiazdowski i Jajor (2005) oraz Sikora i Banachowska (2006). Należy również dodać, że zarówno tiofanat metylowy, jak i azoksystrobina nawet $w$ najwyższych dawkach nie zahamowały całkowicie wzrostu grzybni badanych patogenów (tab. 2). Wśród grzybów rodzaju Fusarium największą wrażliwość na fungicydy $\mathrm{z}$ grupy triazoli stwierdzono $\mathrm{w}$ przypadku $F$. langsethiae, ponieważ wszystkie fungicydy $\mathrm{z}$ tej grupy całkowicie ograniczyły wzrost kultur tego gatunku (tab. 1, 2).

\section{Wnioski / Conclusions}

1. Stopień zahamowania wzrostu kultur grzybów rodzaju Fusarium uzależniony był zwykle od gatunku, użytego fungicydu oraz jego stężenia.

2. Najsilniejsze oddziaływanie fungistatyczne wobec wszystkich badanych gatunków grzybów rodzaju Fusarium stwierdzono w przypadku prochlorazu.

3. Azoksystrobina oraz tiofanat metylowy w najmniejszym stopniu ograniczały wzrost kultur grzybów rodzaju Fusarium.

\section{Literatura / References}

Frużyńska-Jóźwiak D., Andrzejak R. 2010. Wpływ wybranych preparatów na zdrowotność ozdobnych drzew i krzewów iglastych. [The effect of selected preparations on health of ornamental coniferous trees and shrubs]. Prog. Plant. Prot./Post. Ochr. Roślin 50 (4): $2067-2071$.

Gwiazdowski R., Jajor E. 2005. Wrażliwość grzyba Sclerotinia sclerotiorum na wybrane substancje aktywne fungicydów. [The susceptibility of fungi Sclerotinia sclerotiorum to chosen active substances of fungicides]. Prog. Plant. Prot./Post. Ochr. Roślin 45 (2): 701-704.

Ishii H., Tanoue J., Oshima M., Chung W., Nishimura K., Yamaguchi J., Niemoto F., So K., Iwama T., Yoshimatsu H., Shimizu M., Kozawa T. 2008. First application of PCR - Luminex system for molecular diagnosis of fungicide resistance and species identification of fungal pathogens. J. Gen. Plant Pathol. 74: 409-416.

Korbas M., Ławecki T. 2003. Możliwości ograniczania fuzariozy kłosów w Polsce i Unii Europejskiej. [Possibilities of Fusarium ear blight control in Poland and the European Union]. Prog. Plant Prot./Post. Ochr. Roślin 43 (1): 200-207.

Sikora H., Banachowska J. 2006. Wrażliwość grzyba Fusarium culmorum na substancje aktywne wybranych fungicydów. [Susceptibility of the fungus Fusarium culmorum to active ingredient of fungicides]. Prog. Plant Prot./Post. Ochr. Roślin 46 (2): 601-604.

Wojciechowski S., Chełkowski J., Kostecki M. 1995. Influence of deoxynivalenon on electrolite leakage in cereal seedling leaves. Acta Physiol. Plantarum 17 (4): 357-360. 